\title{
UTILIZATION OF OXYGEN QUANTITY AS A COMPOST QUALITY INDICATOR
}

\author{
Saad A.E. Abdelrazek* and H.M. Elkony \\ Soil Salinity and Alkalinity Lab., Alex., Soil, Water and Environ. Res. Inst., Agric. Res. \\ Cent., Giza, Egypt
}

\section{Received: 08/01/2019; Accepted: 02/04/2019}

\begin{abstract}
It is known that the compost plays an affective role in enhancing soil fertility, consequently, plant growth and crops yield, so it is very important to the farmers to get compost has a good quality and distinguished properties. Therefore this study was carried out to investigate the effect of the amount of the oxygen (air) required to convert one $\mathrm{Kg}$ of lettuce, tomatoes, potatoes and turnip plant straw into compost. It was found that there is a relationship between the amount of oxygen and the weight of organic matter which refers to using the amount of $\mathrm{O}_{2}$ as an indicator to the good quality of manufactured compost. In this study, carbon ratio and hydrogen ratio in straw of lettuce, tomato, potato and turnip vegetables and the amount of oxygen (air) required to convert one kilogram of straw into compost was measured. The most important results were that the greater the amount of oxygen used in the fermentation of raw materials, the greater the amount of organic matter, consequently increasing the quality of compost. The amount of oxygen used in the fermentation of raw materials was high for the potato fodder $(6.20 \mathrm{~kg})$ and the amount of organic matter $(813 \mathrm{~g})$ while the amount of oxygen required was less in the leaves of the Lettuce plant $(4.69 \mathrm{~kg})$ and organic matter $(670 \mathrm{~g})$. Therefore, it is important to pay attention to the amount of oxygen required to obtain good compost by knowing the amount of air that is needed to oxidize the organic waste, which is consists all mostly from the hydrocarbon chain (carbon and hydrogen).
\end{abstract}

Key words: Amount of oxygen, quality of compost, organic carbon, and organic matter.

\section{INTRODUCTION}

Compost is one of the most valuable resources for beautifying landscape. The leaves rake, the grass mow, and the branches you trim are some of the ingredients we can use to make compost (Dessalegn et al., 2012).

Finished compost is dark and has a pleasant smell. It is produced when organic matter such as garden, lawn, and kitchen waste is broken down by bacteria and fungi. Use compost throughout landscape: dig it into gardens and flower beds, add it to the soil when renovating lawn, or put it through a sieve and use it in potting soil (Ontario Ministry of the Environment, 2004).

Compost loosens clay soils and helps sandy soils retain water. Adding compost improves soil

\footnotetext{
${ }^{*}$ Corresponding author: Tel. : +20 01006822793

E-mail address: Samad_saad@yahoo.com
}

fertility and stimulates healthy root development in plants. The organic matter provided in compost provides food for microorganisms, which keeps the soil in a healthy, balanced condition. Nitrogen, potassium, and phosphorus will be produced naturally by the feeding of microorganisms, so few if any soil amendments will need to be added (Liang et al., 2016)

Most gardeners have long understood the value of this rich, dark, earthy material in improving the soil and creating a healthful environment for plants (Cooperband, 2012).

Understanding how to make and use compost is in the public interest, as the problem of waste disposal climbs toward a crisis level (Eklind and Kirchmann, 2013).

Landfills are brimming, and new sites are not likely to be easily found. For this reason there is 
an interest in conserving existing landfill space and in developing alternative methods of dealing with waste (Fabrizzi et al., 2009).

A quality standard for compost called PAS100 is given to sites that can demonstrate that they have a high level of control over the inputs and composting process, and that the resulting compost meets strict quality criteria (Jones and O'Hara, 2012).

Good quality compost will then be used for a wide range of different applications, including agriculture, local parks and in floral displays in public spaces (European Compost Network, 2010).

Mixing compost into soil can help to keep the soil $\mathrm{pH}$ in a favourable range, but only if the current soil $\mathrm{pH}$ isn't far from the optimum level (Provenzano et al., 2011).

In order to obtain the quality of this compost, the amount of oxygen to be added to each residue of waste shall be determined according to the percentage of carbon and the hydrogen content of the residue, taking into account the water content of the moisture as well as the percentage of oxygen found in the component (Brinton, 2014).

The respiration test is a relative indicator only of maturity, to be used in conjunction with other physical, chemical, and microbiological measurements to determine the maturity of compost for using

On the other hand, maturity is defined as the condition where compost poses no adverse effects on plants and is determined empirically using bioassays (Marschner and Bunemann, 2008).

In view of the larger number of variables, industry standards for determining maturity are more numerous than those for stability. The decomposition needed to reach maturity vanes with the type of plant grown and the particular agricultural or horticultural practice employed. The crop's nutrients needs, resistance to disease, and the time between compost spreading and the crop planting all affect the decomposition needed for compost to reach maturity (Mohammadi and Torkashvand, 2010).

Using these definitions, it follows that compost which is mature is likely also to be stable. Yet stable compost may not always be at a level of maturity adequate for use as a medium for growing a certain species of plant (Jeong and Kim, 2001).

The objective of this research was to study of obtain in high quality of compost during composting by standard and limited of amount of oxygen as an indicator of compost production.

\section{MATERIALS AND METHODS}

\section{Composting Preparation}

This experiment was conducted at the farm of the Soil Salinity and Alkalinity Research Laboratory at Sabahia Farm in Alexandria Governorate. At least a partially protected spot from the rain was chosen. Vegetable straw of (lettuce, tomato, potato, Turnip) was collected and brought to the preparation site. A layer of vegetable residue $(15 \mathrm{~cm})$ was first worked and then another layer of material is placed in the same sequence and replicated until a height of about $1 \mathrm{~m}$ is reached from the straw inside the boxes.

The water is added to the straw until it is wet enough and water is added regularly. The straw was mixed using a hatching fork after 3 weeks, then again after five weeks; harvesting compost was made after 100 days. Straw of this vegetables were composted in Four $\left(1 \mathrm{~m}^{3}\right)$ perforated plastic boxes for 100 day as aerobic conditions. The material was turned for $0,10,20,30,40$, $60,70,80$ and 100 days. Samples (one $\mathrm{Kg}$ ) were taken, dried at $65^{\circ} \mathrm{C}$, passed after grinding through a $0.2 \mathrm{~mm}$ sieve and stored desecrator. All samples were conducted in tripletail for composting boxes and all samples were analyzed over 100 days. In addition, the content was turn the flipped from time to time.

It is important to measure the temperature as close to the center of the composting material as possible. Typically, a thermometer with a $1 \mathrm{~m}$ long probe is sufficient to achieve this goal. The temperature can vary within the material; it is measure the temperature in a variety of locations (Tateda et al., 2012)

\section{Compost Analysis}

\section{Chemical analyses}

The chemical properties were:

1- Electrical conductivity $\left(\mathrm{EC} \mathrm{dSm}^{-1}\right)$ of the saturated soil extracts measured was using a conductometer (Salcon, 1997). 
2- Soil reaction $(\mathrm{pH})$ of the saturated soil paste was determined using Beckman's $\mathrm{pH}$ meter (Petra and Barbara, 2002).

3- Organic matter was determined, following Walkley and Black method (Bertran and Andreas, 1994).

4- Total Nitrogen (T-N) was determined using an automatic Kaldahl (Bertran and Andreas, 1994).

5- Total phosphorus (T-P) was determined calorimetrically by a spectrophotometer (Watanabe and Olson, 1965).

6- Total Potassium (T-K) was measured by flame photometer (Bertran and Andreas, 1994).

7- Total micro elements composition ( $\mathrm{Fe}, \mathrm{Mn}$ and $\mathrm{Zn}$ ) were determined by atomic absorption spectrophotometer (AAS) (Lindsay and Norvell, 1978).

8- Amount of oxygen from the residual straw of lettuce, tomato, potato and turnip was determined according to carbon (\%) and hydrogen (\%) from Table 1 (FAO, 2018).

\section{Statistical Analysis Method}

The results were analyzed using statistical analysis system, ASA (Steel and Torrie, 1981). Least significant difference at 0.05 level of probability $\left(\mathrm{LSD}_{0.05}\right)$ was used to detect the differences between lettuce, tomato, potato and turnip, Oxygen quantity and compost rate as well as to detect the interaction between all variables used in the study.

Table 1 show the ratio of both hydrogen and carbon which obtained from FAO (2018) and the oxygen ratio of these data was calculated for the four plants from the equation under Table 1 and in terms of the ratio of oxygen in the air $(23 \%)$.

\section{Oxygen Uptake Rate and Carbon Dioxide Evolution Rate}

\section{Advantages}

Oxygen consumption is a good estimate of the amount of biological activity, indicating whether or not the compost is mature and the amount of oxygen needed to get compost is good because it does not leave any traces of mold and weed seeds inside the compost, as a result of the intense heat generated during the construction of the compost (Liang et al., 2016).

\section{RESULTS AND DISCUSSION}

The new definition of Maturity Index a twotiered system is applied beginning with the minimum characterization of the $\mathrm{C}$ : $\mathrm{N}$ ratio and then proceeding to description of at least one parameter (Christian et al., 2009a).

\section{Oxygen Uptake Rate and Carbon Dioxide Evolution Rate}

Heterotrophic organisms (require carbon from organic compounds for their growth). Oxygen is consumed and $\mathrm{CO}_{2}$ is evolved. Both are somewhat related since they both involve the same biological process by different microorganisms (aerobes, anaerobes and fungi). Both measurements and determinations are accepted by TMECC/USDA (Test Methods for the Examination of Composting and Compost), with reservations listed for both methods. Aerobic activity is a function of the composts stability; therefore respiration is directly related to the compost maturity.

\section{Composting of Vegetables Straw}

\section{Temperature}

Show temperature variations during composting time, initially, heat was generated and temperature increased rapidly during the first 10 days from 35 to $55^{\circ} \mathrm{C}$ (mesophilic stage 1). The temperature then remained $>65^{\circ} \mathrm{C}$ for at least the five days (thermophilic stage) necessary for achieving sanitation through reduction of pathogen population below levels that threaten health and to kill all weed seeds and diseases cussing organisms: The temperature then remained almost at an average $55^{\circ} \mathrm{C}$ for about 15 days after which it gradually decreased to reach atmosphere levels after 100 days (maturity stage). It was slow and long about 65 days with no measurable temperature changes. This temperature is considered ideal achieving maximum rates of on decomposition (Harrison, 2017). 
The compost temperature increases due to the microbial activity, and the change is noticeable within a few hours of forming a windrow. The temperature usually increases rapidly to 50 to $60^{\circ} \mathrm{C}$, and this is the level where the temperature is maintained for several weeks. This period is called the active composting stage. The temperature gradually drops to $40^{\circ} \mathrm{C}$ as the active composting slows down and the curing stage begins.

Composting essentially takes place within two temperature ranges: 10 to $40^{\circ} \mathrm{C}$ and higher than $40^{\circ} \mathrm{C}$. Temperatures above $40^{\circ} \mathrm{C}$ are desirable because these higher levels destroy more pathogens, weed seeds and fly larvae in the manure. Composting temperatures of 45 to $65^{\circ} \mathrm{C}$, when extended for more than a two-week period, are able to kill pathogens and destroy the viability of weed seeds.

All biological activity does not always result in complete oxidation of $\mathrm{C}$ to $\mathrm{CO}_{2}\left(\mathrm{CO}_{2}\right.$ evolved may be slightly low). Individual tests are completed over a four-day period though there are no restrictions on the number of tests capable of completing (Table 3).

\section{Stability and Maturity}

Stability relates to microbial activity, more relevant during the early stages of composting. Maturity relates more to the beneficial effects of the compost from a plant viewpoint (Ekinci $\boldsymbol{e t}$ al., 2013).

Table 2 show Classify Compost Maturity, stability refers to a specific stage or decomposition or state of organic matter during composting, which is related to the type of organic compounds remaining and the resultant biological activity in the material. The stability of given compost is important in determining the potential impact of the material on nitrogen availability in soil or growth media and maintaining consistent volume and porosity in container growth media. Most uses of compost require a stable to very stable product that will prevent nutrient tie up and maintain or enhance oxygen availability in soil or growth media.

Table 3 shows the estimated percentage of organic carbon (OC) in a laboratory multiplied by the conversion factor $(1.72 \%)$ to obtain the percentage of the organic matter (OM), including obtaining the quantity of organic matter in $\mathrm{kg}$ to be compared with the quantity of oxygen in $\mathrm{kg}$ (Table 1) and Relationship between quantity $(\mathrm{OM})$ and $\left(\mathrm{O}_{2}\right)$ in Fig. 1. pH recommended in Table 4 was about 6.9 in compost after 100 days, therefore, increases $\mathrm{pH}$ of the organic matter, increasing the soil problems, particularly at high $\mathrm{pH}$ soil such as Egyptian soil. In general $\mathrm{pH}$ in composting wastes ranged between (6.22 -6.55) (Tables 5, 6, 7 and 8) after 100 days. The same results were reached by Grigatti et al. (2007) and Kuo et al. (2004).

The Carbon: Nitrogen $(\mathrm{C} / \mathrm{N})$ ratio of compost is an important factor that determines whether the soil fertility has improved or deteriorated. Overall carbon/ nitrogen ratio between 25:1 and $30: 1$ was considered ideal for starting materials. If the ratio is below this range, $\mathrm{N}$ losses from the pile might be excessive; if the $\mathrm{C} / \mathrm{N}$ ratio is too high, the relative decomposition slows down when the nitrogen is used up and some organisms die (Horan, 2009). The quality is determined by the waste materials that are added to the compost pit. $\mathrm{C} / \mathrm{N}$ ratio in compost as quality standards (20.1) in Table 4 but in Tables $5,6,7$ and 8 after 100 days ranged between (13.86-16.42). BoMyeong and Rosales (2016) reported that green materials like green leaves and green vegetables used for composting were rich in nitrogen content.

EC values that limit the use of compost in this plants as soil fertilizer were illustrated by Tables 5, 6, 7 and 8 which rarged between (3.39- $5.91 \mathrm{dSm}^{-1}$ ) in the final product of the four plants, where the stander value of electrical conductivity (1.3) as in Table 4. Same results were reported by Atiyeh et al. (2011) and Carmona et al. (2012).

Tables (5-8) show the percentage of organic matter OM (\%) which were higher than the international standards (27.2\%) showed at Table 4 , which indicates the richness of these wastes and the need to benefit from the process of composting to compensate the poor land, especially sandy and limestone soil, for the absence of dynamic. 
Table 1. Calculation amount of oxygen required to get compost from lettuce, tomato, potato and turnip

\begin{tabular}{lcccc}
\hline \multirow{2}{*}{ Parameter } & $\mathbf{C}$ & $\mathbf{H}$ & $\mathbf{O}_{\mathbf{2}}$ & air \\
\cline { 2 - 5 } Plants & $\mathbf{( \% )}$ & $\mathbf{( \% )}$ & $\mathbf{k g}$ & $\mathbf{k g}$ \\
\hline Lettuce plant (Lactuea sativa) & 62 & 38 & 4.69 & 20.39 \\
Tomato plant (Lycopersicon esculentum $\mathbf{~ L . )}$ & 53 & 47 & 5.17 & 22.48 \\
Potato (Solanum tuberosum $\mathbf{L .}$ ) & 44 & 56 & 6.20 & 26.96 \\
Turnip plant(Brassica napus) & 84 & 16 & 5.28 & 22.96 \\
LSD p<0.05 & ----- & ----- & 0.17 & 4.1 \\
\hline
\end{tabular}

Carbon (\%) and hydrogen (\%) from FAO (2018)

$\mathrm{C}$ equation $=\mathrm{C}_{12}+\mathrm{O}_{16 \times 2}=\mathrm{CO}_{2}$

$\mathrm{H}$ equation $=\mathrm{H}_{1}+{ }^{1 / 2} \mathrm{O}_{2}=\mathrm{H}_{2} \mathrm{O}$

$\mathrm{O}_{2}=23 \%$ from air

Table 2. Proposed three tier systems to classify compost maturity

\begin{tabular}{lcc}
\hline Very matture & Mature & Immature \\
\hline Well cured compost & Cured compost & Uncured compost \\
No continued decomposition & Odor production not likely & Odors likely \\
No potential toxicity & Limited toxicity potential; Minimal impacts on soil N & High toxicity potential \\
\hline
\end{tabular}

Table 3. The net amount of organic matter in compost produced from straw of lettuce, tomato, potatoes and turnip

\begin{tabular}{lccc}
\hline Plant & OC $^{*}$ & Convert factors & OM \\
\cline { 2 - 2 } & $\mathbf{( \% )}$ & & $\mathbf{( \% )}$ \\
\hline Lettuce plant (Lactuea sativa) & 39 & & 67.08 \\
Tomato plant (Lycopersicon esculentum) & 42 & 1.72 & 72.24 \\
Potato (Solanum tuberosum $\mathbf{L}$.) & 47 & & 80.84 \\
Turnip plant (Brassica napus) & 43 & 73.96 \\
LSD p<0.05 & 4.2 & 3.3 \\
\hline
\end{tabular}

OM (Organic matter)* easy compared with $\mathrm{O}_{2}$ quantity * OC (Organic Carbon)

* 16\%co Oxygen uptake less than $150 \mathrm{mg} \mathrm{O} / \mathrm{kg}$ organic matter/hour 


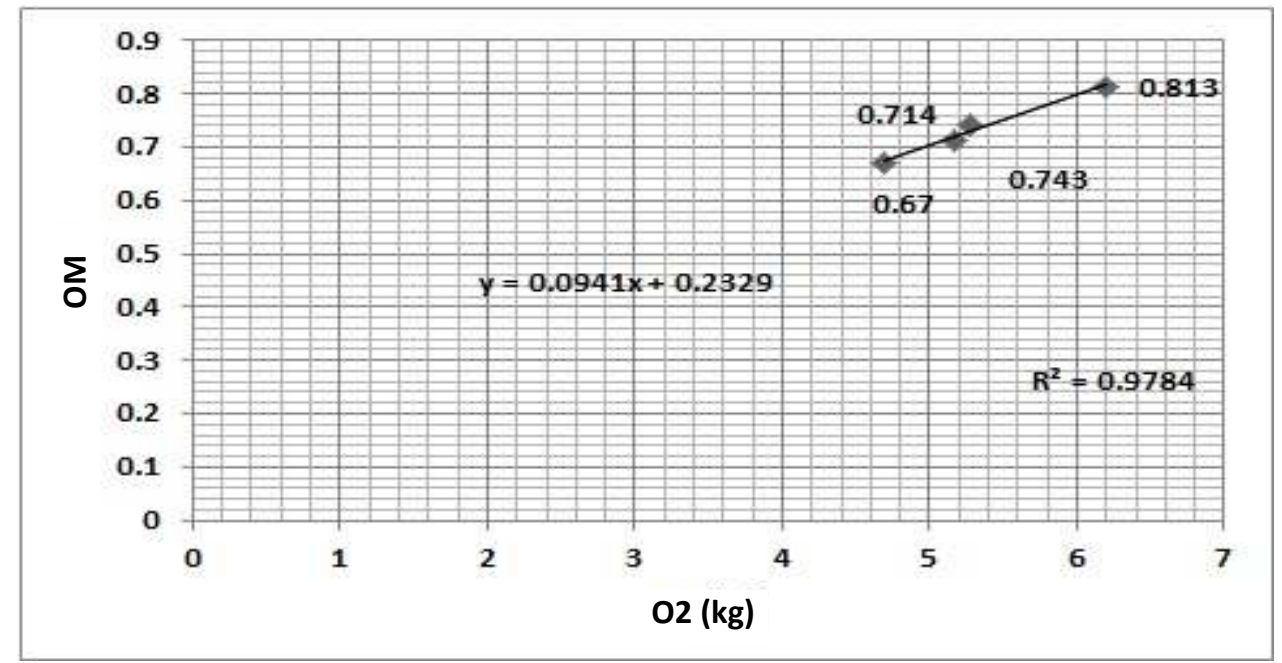

Fig. 1. Relationship between organic matter $(\mathrm{OM})$ and oxygen $\left(\mathrm{O}_{2}\right)$

Table 4. End-Use Test Values Recommended for Compost: Category Potting Mixes (Stability and Mature) comparison of quality standards for compost used in agriculture as FAO, 2018 (100 day on dry matter basis)

\begin{tabular}{ccccccccccccc}
\hline $\begin{array}{c}\text { Composting } \\
\text { time }\end{array}$ & $\mathbf{p H}$ & $\begin{array}{c}\text { EC } \\
\mathbf{d S m}^{-\mathbf{1}}\end{array}$ & $\begin{array}{c}\text { OM* } \\
\mathbf{( \% )}\end{array}$ & $\begin{array}{c}\text { T.N } \\
\mathbf{( \% )}\end{array}$ & $\begin{array}{c}\text { T.P } \\
\mathbf{( \% )}\end{array}$ & $\begin{array}{c}\text { T.K } \\
\mathbf{( \% )}\end{array}$ & $\begin{array}{c}\text { T.Fe } \\
\mathbf{( \% )}\end{array}$ & $\begin{array}{c}\text { T.Mn } \\
\mathbf{M g k g}^{-1}\end{array}$ & $\begin{array}{c}\text { T.Zn } \\
\mathbf{M k g}^{-1}\end{array}$ & $\begin{array}{c}\text { C/Natio } \\
\text { rash content }\end{array}$ & $\begin{array}{c}\text { Ash } \\
(\%)\end{array}$ \\
\hline $\mathbf{1 0 0}$ & 6.9 & 1.3 & 27.2 & 0.8 & 2.05 & 0.37 & 0.42 & 0.32 & 2.8 & 20.0 & 72.80 \\
\hline
\end{tabular}

OM: Organic Matter (\%) T.N: Total Nitrogen (\%) T.P: Total Phosphorous (\%) T.K: Total Potassium (\%)

$\mathrm{C} / \mathrm{N}$ ratio: Total carbon/Total Nitrogen in compost. T.Fe : Total Iron T .Mn : Total Manganese T.Zn : Total Zink

LSD : least significant differences

Table 5. Chemical properties of lettuce plant (Lactuea sativa) compost during the composting process (on dry matter basis)

\begin{tabular}{|c|c|c|c|c|c|c|c|c|c|c|c|}
\hline $\begin{array}{l}\text { Composting } \\
\text { time (day) }\end{array}$ & pH & $\begin{array}{c}\mathrm{EC} \\
\mathrm{dSm}^{-1}\end{array}$ & $\begin{array}{l}\text { OM } \\
(\%)\end{array}$ & $\begin{array}{l}\text { T.N } \\
(\%)\end{array}$ & $\begin{array}{l}\text { T.P } \\
(\%)\end{array}$ & $\begin{array}{l}\text { T.K } \\
(\%)\end{array}$ & $\begin{array}{l}\mathrm{Fe} \\
(\%)\end{array}$ & $\begin{array}{c}\text { Mn } \\
\text { Mgkg }^{-1}\end{array}$ & $\begin{array}{c}\mathrm{Zn} \\
\text { Mgkg }^{-1}\end{array}$ & $\begin{array}{l}\mathrm{C} / \mathrm{N} \\
\text { ratio }\end{array}$ & $\begin{array}{c}\text { Ash content } \\
(\%)\end{array}$ \\
\hline $\mathbf{0}$ & 7.87 & 3.55 & 83.80 & 1.62 & 0.39 & 0.66 & 0.44 & 0.88 & 1.55 & 30.07 & 16.20 \\
\hline 10 & 7.84 & 3.45 & 87.60 & 1.70 & 0.36 & 0.74 & 0.46 & 0.89 & 1.56 & 29.95 & 12.40 \\
\hline 20 & 7.82 & 3.25 & 85.90 & 1.99 & 0.44 & 0.86 & 0.52 & 0.91 & 1.65 & 25.10 & 14.10 \\
\hline 30 & 7.75 & 3.40 & 78.60 & 2.02 & 0.45 & 0.88 & 0.53 & 0.93 & 1.74 & 22.62 & 21.40 \\
\hline 40 & 7.45 & 3.60 & 77.40 & 2.13 & 0.54 & 0.95 & 0.64 & 0.94 & 1.75 & 21.13 & 22.6 \\
\hline 60 & 7.87 & 3.70 & 75.60 & 2.34 & 0.65 & 0.96 & 0.66 & 0.95 & 1.90 & 18.78 & 24.40 \\
\hline 70 & 7.43 & 4.60 & 68.90 & 2.76 & 0.66 & 1.42 & 0.67 & 0.96 & 1.95 & 14.51 & 31.20 \\
\hline 80 & 7.18 & 5.81 & 67.90 & 2.77 & 0.71 & 1.66 & 0.78 & 0.97 & 2.10 & 14.25 & 32.10 \\
\hline 100 & 6.22 & 5.91 & 66.25 & 2.78 & 0.85 & 1.88 & 0.79 & 0.98 & 2.10 & 13.86 & 33.75 \\
\hline $\operatorname{LSD}_{(0.05)}$ & 0.26 & 0.36 & 2.85 & 0.11 & 0.030 & 0.04 & 0.03 & 0.03 & 16 & 1.4 & 2.4 \\
\hline
\end{tabular}

See footnote of Table 4 
Zagazig J. Agric. Res., Vol. 46 No. (2) 2019

Table 6. Chemical properties of tomato plant (Lycopersicon esculentum L.) compost during the composting process (on dry matter basis)

\begin{tabular}{cccccccccccc}
\hline $\begin{array}{c}\text { Composting } \\
\text { time (day) }\end{array}$ & $\mathbf{p H}$ & $\begin{array}{c}\text { EC } \\
\mathbf{d S m}^{-1}\end{array}$ & $\begin{array}{c}\text { OM } \\
(\%)\end{array}$ & $\begin{array}{c}\text { T.N } \\
\mathbf{( \% )}\end{array}$ & $\begin{array}{c}\text { T.P } \\
\mathbf{( \% )}\end{array}$ & $\begin{array}{c}\text { T.K } \\
(\%)\end{array}$ & $\begin{array}{c}\text { T.Fe } \\
(\mathbf{\%})\end{array}$ & $\begin{array}{c}\text { T.Mn } \\
\mathbf{M g k g}^{-1}\end{array}$ & $\begin{array}{c}\text { T.Zn } \\
\mathbf{M g k g}^{-1}\end{array}$ & $\begin{array}{c}\text { C/N } \\
\text { ratio }\end{array}$ & $\begin{array}{c}\text { Ash content } \\
(\%)\end{array}$ \\
\hline $\mathbf{0}$ & 7.86 & 3.60 & 86.70 & 1.53 & 0.36 & 0.65 & 0.33 & 0.74 & 1.55 & 32.94 & 13.30 \\
$\mathbf{1 0}$ & 7.85 & 2.55 & 87.90 & 1.56 & 0.34 & 0.74 & 0.34 & 0.75 & 1.56 & 32.76 & 12.10 \\
$\mathbf{2 0}$ & 7.82 & 3.30 & 86.40 & 1.6 & 0.45 & 0.83 & 0.35 & 0.77 & 1.66 & 31.39 & 13.60 \\
$\mathbf{3 0}$ & 7.73 & 3.50 & 82.30 & 1.74 & 0.55 & 0.85 & 0.44 & 0.81 & 1.75 & 27.50 & 17.70 \\
$\mathbf{4 0}$ & 7.45 & 3.60 & 76.90 & 1.77 & 0.62 & 0.92 & 0.47 & 0.83 & 1.79 & 25.26 & 23.10 \\
$\mathbf{6 0}$ & 7.89 & 4.25 & 76.80 & 2.33 & 0.74 & 0.96 & 0.55 & 0.84 & 1.85 & 19.16 & 23.20 \\
$\mathbf{7 0}$ & 7.40 & 4.30 & 75.60 & 2.40 & 0.84 & 1.18 & 0.59 & 0.95 & 1.99 & 18.31 & 24.40 \\
$\mathbf{8 0}$ & 7.20 & 4.65 & 73.50 & 2.50 & 0.92 & 1.25 & 0.61 & 0.93 & 2.14 & 17.09 & 26.50 \\
$\mathbf{1 0 0}$ & 6.35 & 4.68 & 71.40 & 2.66 & 0.97 & 1.35 & 0.66 & 0.91 & 2.16 & 15.61 & 28.60 \\
$\mathbf{L S D}_{\mathbf{( 0 . 0 5 )}}$ & 0.28 & 0.41 & 2.91 & 0.12 & 0.050 & 0.06 & 0.02 & 0.02 & 17 & 1.6 & 2.34 \\
\hline
\end{tabular}

See footnote of Table 4

Table 7. Chemical properties of potato (Solanum tuberosum $\mathbf{L}$.) compost during the composting process (on dry matter basis)

\begin{tabular}{cccccccccccc}
\hline $\begin{array}{c}\text { Composting } \\
\text { time (day) }\end{array}$ & $\mathbf{p H}$ & $\begin{array}{c}\text { EC } \\
\mathbf{d S m}^{-\mathbf{1}}\end{array}$ & $\begin{array}{c}\text { OM } \\
(\mathbf{\%})\end{array}$ & $\begin{array}{c}\text { T.N } \\
\mathbf{( \% )}\end{array}$ & $\begin{array}{c}\text { T.P } \\
\mathbf{( \% )}\end{array}$ & $\begin{array}{c}\text { T.K } \\
(\%)\end{array}$ & $\begin{array}{c}\text { T.Fe } \\
(\mathbf{\%})\end{array}$ & $\begin{array}{c}\text { T.Mn } \\
\mathbf{M g k g}^{-1}\end{array}$ & $\begin{array}{c}\text { T.Zn } \\
\mathbf{M g k g}^{-1}\end{array}$ & $\begin{array}{c}\text { C/N } \\
\text { ratio }\end{array}$ & $\begin{array}{c}\text { Ash content } \\
(\%)\end{array}$ \\
\hline $\mathbf{0}$ & 7.87 & 3.26 & 90.70 & 1.22 & 0.39 & 0.65 & 0.33 & 0.77 & 1.56 & 43.22 & 9.3 \\
$\mathbf{1 0}$ & 7.85 & 3.18 & 91.20 & 1.23 & 0.46 & 076 & 0.34 & 0.78 & 1.60 & 43.11 & 8.80 \\
$\mathbf{2 0}$ & 7.82 & 3.05 & 89.90 & 1.77 & 0.49 & 0.86 & 0.36 & 0.84 & 1.70 & 29.53 & 10.1 \\
$\mathbf{3 0}$ & 7.76 & 3.11 & 89.70 & 1.88 & 0.54 & 0.87 & 0.41 & 0.86 & 1.74 & 27.74 & 10.30 \\
$\mathbf{4 0}$ & 7.50 & 3.15 & 89.60 & 1.90 & 0.62 & 0.95 & 0.46 & 0.89 & 1.78 & 27.42 & 10.40 \\
$\mathbf{6 0}$ & 7.88 & 3.19 & 87.40 & 2.15 & 0.77 & 0.98 & 0.47 & 0.91 & 1.90 & 23.63 & 12.60 \\
$\mathbf{7 0}$ & 7.44 & 3.32 & 84.50 & 2.18 & 0.85 & 1.26 & 0.48 & 0.93 & 2.25 & 22.54 & 15.5 \\
$\mathbf{8 0}$ & 7.17 & 3.35 & 83.60 & 2.35 & 0.91 & 1.33 & 0.49 & 0.96 & 2.32 & 20.68 & 16.40 \\
$\mathbf{1 0 0}$ & 6.41 & 3.39 & 81.32 & 2.88 & 0.93 & 1.35 & 0.51 & 0.98 & 2.40 & 16.42 & 18.68 \\
$\mathbf{L S D}_{(\mathbf{0 . 0 5})}$ & 0.29 & 0.37 & 2.88 & 0.13 & 0.040 & 0.06 & 0.01 & 0.01 & 18 & 1.6 & 2.37 \\
\hline
\end{tabular}


Table 8. Chemical properties of turnip plant (Brassica napus) compost during the composting process (on dry matter basis)

\begin{tabular}{cccccccccccc}
\hline $\begin{array}{c}\text { Composting } \\
\text { time (day) }\end{array}$ & $\mathbf{p H}$ & $\begin{array}{c}\mathbf{E C} \\
\mathbf{d S m}^{-1}\end{array}$ & $\begin{array}{c}\text { OM } \\
(\%)\end{array}$ & $\begin{array}{c}\text { T.N } \\
\mathbf{( \% )}\end{array}$ & $\begin{array}{c}\text { T.P } \\
\mathbf{( \% )}\end{array}$ & $\begin{array}{c}\text { T.K } \\
(\mathbf{\%})\end{array}$ & $\begin{array}{c}\text { T.Fe } \\
(\mathbf{\%})\end{array}$ & $\begin{array}{c}\text { T.Mn } \\
\mathbf{M g k g}^{-1}\end{array}$ & $\begin{array}{c}\text { T.Zn } \\
\mathbf{M g k g}^{-1}\end{array}$ & $\begin{array}{c}\text { C/N } \\
\text { ratio }\end{array}$ & $\begin{array}{c}\text { Ash content } \\
(\%)\end{array}$ \\
\hline $\mathbf{0}$ & 7.88 & 3.45 & 83.70 & 1.82 & 0.37 & 0.74 & 0.22 & 0.66 & 1.55 & 26.74 & 16.30 \\
$\mathbf{1 0}$ & 7.86 & 2.40 & 84.90 & 1.88 & 0.38 & 0.76 & 0.21 & 0.67 & 1.62 & 26.26 & 15.10 \\
$\mathbf{2 0}$ & 7.84 & 3.10 & 83.50 & 1.90 & 0.46 & 0.86 & 0.19 & 0.68 & 1.65 & 25.55 & 16.50 \\
$\mathbf{3 0}$ & 7.77 & 3.80 & 81.60 & 2.25 & 0.64 & 0.87 & 0.18 & 0.74 & 1.78 & 21.09 & 18.40 \\
$\mathbf{4 0}$ & 7.50 & 3.49 & 79.30 & 2.66 & 0.74 & 0.92 & 0.17 & 0.75 & 1.85 & 17.33 & 20.70 \\
$\mathbf{6 0}$ & 7.88 & 3.50 & 78.52 & 2.72 & 0.76 & 0.95 & 0.6 & 0.77 & 1.99 & 16.78 & 21.48 \\
$\mathbf{7 0}$ & 7.45 & 3.55 & 77.50 & 2.85 & 0.85 & 1.10 & 0.15 & 0.81 & 2.10 & 15.81 & 22.50 \\
$\mathbf{8 0}$ & 7.20 & 3.56 & 76.60 & 2.90 & 0.91 & 1.18 & 0.14 & 0.88 & 2.20 & 15.36 & 23.40 \\
$\mathbf{1 0 0}$ & 6.55 & 3.58 & 74.33 & 2.93 & 0.98 & 1.25 & 0.13 & 0.97 & 2.30 & 14.75 & 25.67 \\
$\mathbf{L S D}_{(\mathbf{0 . 0 5})}$ & 0.25 & 0.38 & 2.91 & 0.15 & 0.070 & 0.06 & 0.02 & 0.02 & 18 & 1.5 & 2.34 \\
\hline
\end{tabular}

See footnote of Table 4

source where it is known that mud and organic matter are the source of dynamism in the agriculture land. The mean values of organic matter in the crop residues ranged between $(66.25-81.32)$ at 100 day maturity. These results are in agreement with those reported by Sanchez et al. (2014) and Ribeiro et al. (2017).

\section{Chemical Properties}

Chemical properties very important as a result for air (oxygen) input during composting time and the composting process (Fig. 2). The Chemical properties determined were electrical conductivity (EC) $\mathrm{pH}, \mathrm{NO}_{3}-\mathrm{N}$, total nitrogen ( $\mathrm{T}$ $\mathrm{N})$, Total carbon (T-C), total potassium (T-K), total manganese (T-Mn), total zinc (T-Zn) and ash content (Tables 7, 8, 9 and 10). The sum of soluble ions in the water extracts as indicated by EC measurements increased slightly at the beginning of composting due to the release of easily decomposable compounds into the solution (Tiquia, 2015).

During the first 40 days no significant change insoluble ion concentration occurred. During maturation, the EC increased sharply in the solution reaching a maximum at 80 days or more (Christian et al., 2009b).

The $\mathrm{pH}$ of the fresh manure for lettuce, tomato, potato and turnip was $(7.87,7.86,7.87$ and 7.88) respectively, then the $\mathrm{pH}$ decreased slightly at the beginning of the compositing process due to accumulation of organic acids as reflected by increased alkalinity. After this, the acids were utilized as substrates by other aerobic microbes and the $\mathrm{pH}$ increased during the mesophilic stage (first stage). During the maturation stage the $\mathrm{pH}$ dropped close to neutral values, then stabilized. This pattern is typical for the composting process (El-Kouny et al., 2004). Optimum $\mathrm{pH}$ levels for the composting within the range of lettuce, tomato, potato, and turnip (6.22, 6.35, 6.41, and 6.55) (Table 1). Realy, this activity is known to be inhibited at high temperature above $40^{\circ} \mathrm{C}$ (Gea et al., 2004). Total elemental composition was determined ( $\mathrm{T}$ N,T-P,T-K, T-Fe,T-Mn and T-Zn) by wet digestion and is show in (Tables 5, 6, 7 and 8). The concentration of most of the elements determined was increased with the corresponding loss of OM. The main changes occurred during the first 40 days as already has been reported for the narrowly $\mathrm{C} / \mathrm{N}$ Ratio for lettuce, tomato, potato, turnip (from (30.07-13.86), (32.9415.61), (43.22-16.42) and (26.74-14.75) respectively, and increasing ash content (from 16.30\% $25.67 \%),(9.3 \%-18.68 \%),(13.30 \%-28.60 \%)$ and $(16.20 \%-33.75 \%)$. 


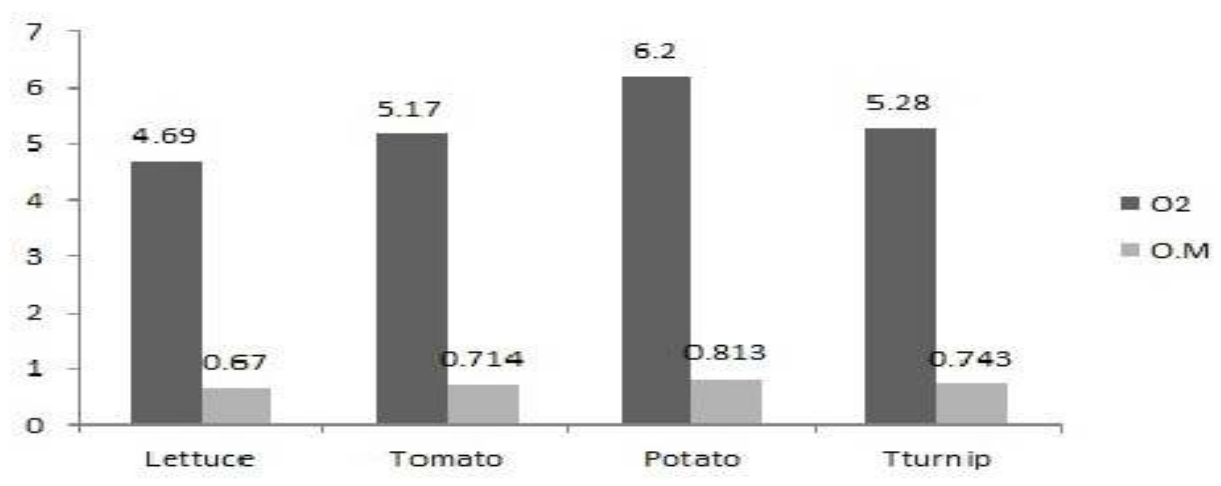

Fig. (2). Content of organic matter (O.M) and oxygen $\left(\mathrm{O}_{2}\right)$ in different compost materials

The most important results were that the greater the amount of oxygen used in the fermentation of raw materials the greater the amount of organic matter and thus increased the quality of compost. Therefore, it is important to pay attention to the amount of oxygen required to obtain a good compost by knowing the amount of air that is required to oxidize the organic waste, which is in hydrogen and carbon as the organic matter is a hydrocarbon series (carbon and hydrogen, the basic component of raw organic matter).

\section{Conclusions}

The following conclusions: Relatively inexpensive and simple to operate good indicator of stability but not for following maturity, good signal response without $\mathrm{O}_{2}$ transfer limitations with solid matrix, robust indicator used successfully with a wide range of the raw material types.

\section{Recommendations}

Attention should be given to the amount of oxygen needed to obtain good compost.

\section{REFERENCES}

Atiyeh, R.M., C.A. Edwards, S. Subler and J.D. Metzger (2011). Vegetables manure as a component of a horticultural bedding plant medium: effect on physicochemical properties and plant growth. Bioresource Technol., 78: 11-20.
Bertran, K., H. and R. Andreas (1994). Methods Book for Analysis of compost, publisher: Federal Compost Quality Asuran Organization (FCQAQ).

Bo Myeong, W. and E. Rosales (2016). Making Compost. Jamaica: Int. Ame. Inst. Coorporation on Agric.

Brinton, W. (2014). Compost Quality Standards and Guidelines: Compost quality in America. Woods end Res. Laboratory incorporated, New York

Carmona, E., M.T. Moremo, M. Aviles, J. Ordovas (2012). Use of grape marc compost as substrate for vegetable seedlings. Scientia Hort., 137:(69-74)

Christian, A.H., G.K. Evanylo and James W. Pease (2009a). On-Farm Composting: A Guide to Principles, Planning, and Operations. Virginia Cooperative Extension publication (452-232)http://pubs.ext.vt.edu/452/452-232/ 452-232_pdf.pd

Christian, A.H., G.K. Evanylo and R. Green (2009b). Compost: What Is It and What's It to You? Virginia Cooperative Extension publication, Article: (452-431)

Cooperband, L. (2012). The Art and Science of Composting: A resource for farmers and Compost producers. Center for Integrated agricultural systems; Wisconsin Univ., Madison. 
Dessalegn, D., H. Sulaiman and L. Seyoumeta (2012). Evaluation of composting and the quality of compost from the source separated municipal solid waste, JASEM ISSN 11198362 All Rights Reserved, 16 (1): 5 - 10.

Ekinci, K., H.M. Keener and D.L. Elwell (2013). Composting short paper fiber with broiler litter and additives: I. Effect of initial $\mathrm{pH}$ and carbon/nitrogen ratio on ammonia emission. Comp. Sci. Utiliz., 8: 160-172.

Eklind, Y. and H. Kirchmann (2013). Composting and storage of organic household waste with different litter amendments. II. Nitrogen turnover and losses. Bioresour Technol., 74 (2): 125-133.

El-Kouny, H.M., A.M. El-Assar and S.G. Mohamed (2004). Effectiveness of natural organic amendments. Biologically activated composted and mineral fertilization sources of potassium in improving soil properties and

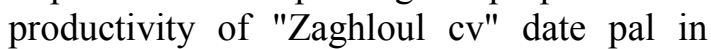
calcareous soil. Assiut J. Agric. Sci., 25: 2-4.

European Compost Network (2010). European Quality Assurance for Compost is launched, in ECN Info paper, 6.

Fabrizzi, K.P., C.W. Rice, T.J.C. Amado, J. Fiorin, P. Barbagelata and R. Melchiori (2009). Protection of soil organic C and N in temperate and tropical soils: effect of native and agroecosystems. Biogeochem., 92:129143.

FAO (2018). Food security and nutrition in the world, ISBN 978-92-5-130571-3

Gea, T., R. Barrena, A.E. Artola and A. Sánchez (2004). Monitoring the Biological Activity of the Composting Process: Oxygen Uptake Rate (OUR), Respirometric Index (RI), and Respiratory Quotient (RQ) Biotechnol. Bioeng, 88: 520-527. doi: 10.1002/bit.20281

Grigatti, M., M.E. Giorgioni and C. Ciavatta (2007). Compost-based growing media: Influence on growth and nutrient use of bedding plants. Bioresource Technol., 98: 3526-3534.

Harrison, E.Z. (2017). Compost Facilities: OffSite Air Emissions and Health- Summary of the literature, Cornell Waste Manag. Inst., 23.

Horan, M.V. (2009). Compost Production and utilization. $1^{\text {st }}$ Ed. SL: Fertilizer research and education program.

Jeong, Y.K. and J.S. Kim (2001). A new method for conservation of nitrogen in aerobic composting processes. Bioresour. Technol., 79: 129-133.

Jones, D.A. and K.L. O'Hara (2012). Carbon density in managed coast redwood stands: implications for forest carbon estimation, Forestry, 85: 99-110.

Kuo, S., M.E. Ortiz-Escobar, N.V. Hue and R.L. Hummel (2004). Composting and compost utilization for agronomic and container crops. Recent Res. Develop. Environ. Biol., 1: 451-513.

Liang, Y., J.J. Leonard, J.J.R. Feddes and W.B. McGill (2016). Influence of carbon and buffer amendment on ammonia volatilization in composting. Bioresour Technol., 97: 748761.

Lindsay, W. and W. Norvell (1978). Development of DTPA test for $\mathrm{Zn}, \mathrm{Fe}, \mathrm{Mn}$ and $\mathrm{Cu}$. Soil Sci. Soc. Ame. J., 42 : 421-427.

Marschner, H.A.K.V.P. and E.K. Bunemann (2008). Dynamics of C, N, P and microbial community composition in particulate soil organic matter during residue decomposition. Plant Soil, 303: 253-264.

Mohammadi, B. and A. Torkashvand (2010). improvement of compost quality by addition of some amendments, Aust. J. Crops Sci. AJCS, 4 (4): 252-257.

Ontario Ministry of the Environment (2004). Interim Guidelines for the production and use of aerobic compost in Ontario. Ontario.

Petra. S. and W. Barbara (2002). Improved reliability of $\mathrm{pH}$ measurements, Analytical and Bioanalytical Chem., 374 (5): 787-795.

Provenzano, M.R., S.C.De. Oliveira, M.R.S. Silva and N. Senesi (2011). Assessment of maturity degree of compost from domestic solid wastes by fluorescence and Fourier 
transform infrared spectroscopy. J. Agric. Food Chem., 49 : 5874-5879.

Ribeiro, H.M., A.M. Romero, H. Pereira, P. Borges, F. Cabral and E. Vasconcelos. (2017). Evaluation of a compost obtained from forestry wastes as a substrate for seedlings production. Bioresource Technol., 98: 3294-3297.

Salcon (1997). Salinity Management Handbook. Dept. Nat. Res., Indooroopilly.

Sanchez, M.M., A. Roig, A. Cegarra, J. Bernal, M.P. Noguera, P. Abad and M.A. Anton (2014). Compost as media constituents for vegetable transplant production. Comp. Sc. and Utiliz., 12: 161-168.
Steel, R.G.D. and J.H. Torrie (1981). Principals and Procedures of Statistics. $2^{\text {nd }}$ Ed., Mcgrawhill Int. Com. Book Comp., 633-639.

Tateda, M., L.D. Trung, N. Hung, V. Ike and M.M Fujita (2012). Comprehensive temperature monitoring in an in-vessel forced-aeration staticbed composting process. J. Material Cycles and Waste Manag., 4 : 62-69.

Tiquia, S.M. (2015). Microbiological parameters as indicators of compost maturity, J. Appl. Microbiol., 99: 816-828.

Watanabe, F.S. and Olson, S.R. (1965): Test of an ascorbic acid method for determining phosphorus in water and $\mathrm{NaHCO}_{3}$ extracts from soil. Soil Sci. Soc. Am. Proc. 29: 677-678.

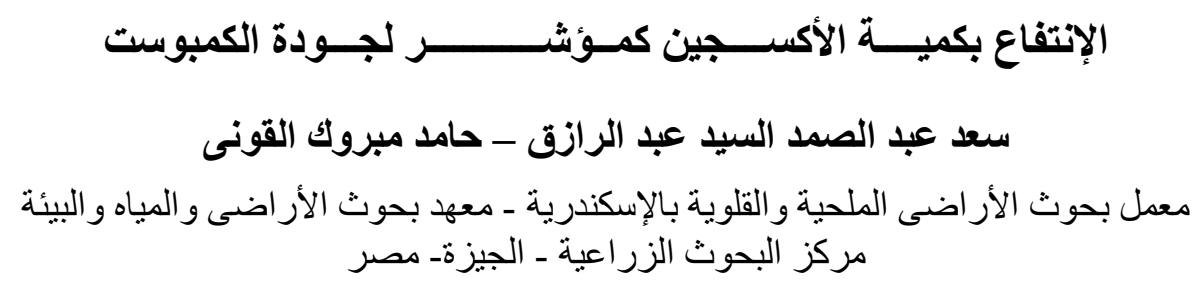

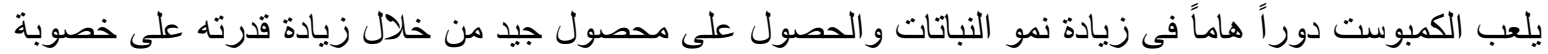

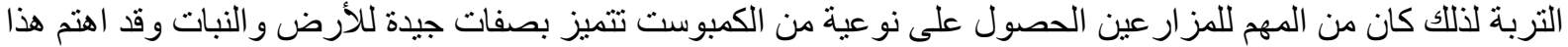

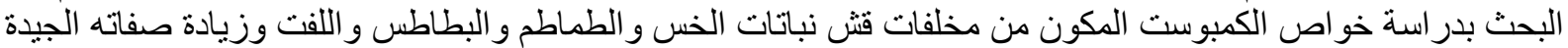

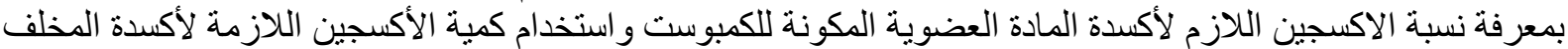

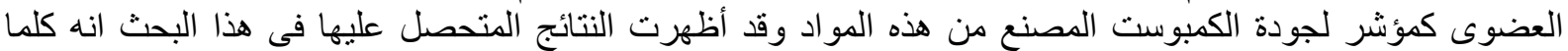

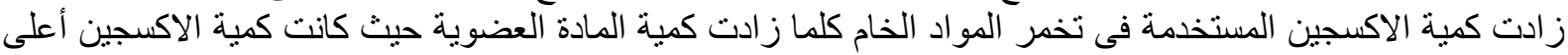

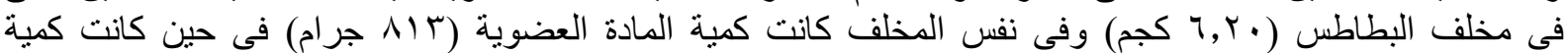

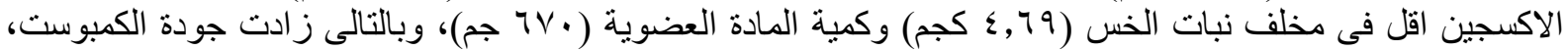

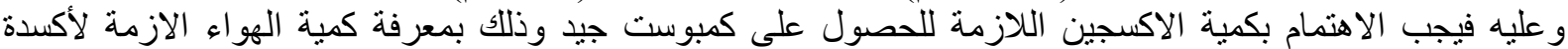

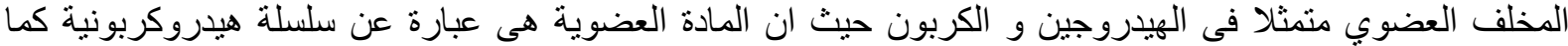
يعتبر الكربون و الهيدروجين المكونان الأساسيان للمادة العضوية الكيد الخام. الكلمات الإسترشادية: كمية الأكسجين، جودة الكمبوست، الكربون العضوى، المادة العضوية.

أستاذ الأر اضى ـ كلية الزر اعة ـ جامعة المنوفية.

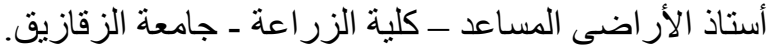

